\title{
クロム鉱石の溶融環元におよぼす フラックス組成の影響
}

\author{
横山 誠二**武田 光正 ${ }^{*} \cdot$ 大楠 洋 $* 3$. \\ 伊藤 公允 ${ }^{*} \cdot$ 川上 正博*
}

\section{Effect of Flux Compositon on Smelting Reduction of Chromite Ore}

\author{
Seiji Yoкоyama, Mitsumasa Takeda, Hiroshi Oogusu, Koin Ito and Masahiro KawakamI
}

\begin{abstract}
Synopsis :
The smelting reduction behavior of chromite ore in molten slag of $(\mathrm{CaO})-\left(\mathrm{SiO}_{2}\right)-\left(\mathrm{Al}_{2} \mathrm{O}_{3}\right)-(\mathrm{MgO})$ system by carbon in liquid iron held in graphite crucible has been studied in the temperature range of $1663 \mathrm{~K}-1953$ $\mathrm{K}$. The reduction rate was expressed by the zeroth-order rate equation at an early stage of smelting reduction. During this stage, both $(\mathrm{CrO})$ and the rate were kept constant and unaffected by the dissolution of the ore into slag with the exception that the ore in flux contained 15 mass $\%\left(\mathrm{Al}_{2} \mathrm{O}_{3}\right)$ and 15 mass $\%$ $(\mathrm{MgO})$ was reduced at $1783 \mathrm{~K}$. Accordingly, the slag was considered to be saturated with $(\mathrm{CrO})$. The rate decreased with an increase in $\left(\mathrm{Al}_{2} \mathrm{O}_{3}\right)$ and $(\mathrm{MgO})$ contents. In particular, it decreased with the former. On the other hand, the rate increased with $(\mathrm{CaO}) /\left(\mathrm{SiO}_{2}\right)$ ratio as it increased up to unity. When the ratio exceeded unity, the rate obtained at $1783 \mathrm{~K}$ was unchanged with the ratio, whereas the rate at $1903 \mathrm{~K}$ decreased with the ratio. The rate constant was in proportion to -0.80 power of slag viscosity.

Key words : smelting reduction; chromite ore; dissolution; saturation value.
\end{abstract}

\section{1. 緒言}

近年, 電力によらないフェロクロムやステンレス粗溶 晹の新製造法として，クロム鉱石の溶融還元法が注目さ れ, 研究が行われている ${ }^{1)-4)}$. 筆者らもクロム鉱石を底 から吹きこんで溶鉄中炭素とけい素による還元について 研究を行ってきた ${ }^{5)}$-9). 難溶融性なクロム鉱石の還元反 忍促進のために, 実際の溶融還元ではフラックスが添加 されている，筆者らの底吹き還元においても，溶鉄表面 上にスラグを置くと，溶鉄中で還元しつくされなかった 鉱石を還元できるので, クロムの回収率が増加する結果 を得ている．したがって，スラグ中のクロム鉱石の溶融

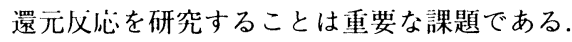

本報告ではクロム鉣石溶還元の基礎研究の一環とし て，還元速度におよぼすフラックス組成の影響について 検討した．スラグ中クロム鉱石の溶融還元仪心は鉱石の
スラグへの溶解とスラグ中クロム酸化物の還元の二つの 過程を経ると思われる. 従来フラックス組成の還元速 度におよぼす影響について調べられているが，それが どの反応過程に影響をおよぼしているかは明確ではな (10) - 14). そこで本報告ではクロム鉱石の溶解過程と還 元過程を分けて考え, 反応機構を検討した.

\section{2. 実 験 方 法}

\section{$2 \cdot 1$ 実験装置}

実験に使用した装置の概略を Fig. 1 に示す. 反応管は 内径 $66 \mathrm{~mm}$, 長さ $500 \mathrm{~mm}$ の不透明石英管で上下に真 ちゅう製の水冷キャップを取り付けてある. 上部キャッ プにはクロム鉱石とフラックスの投入口を兼ねたスラグ 試料採取口，および測温とガス導人口を兼ねた溶鉄試料 採取口，そして下部キャップにはガス排出口をそれぞれ 備えてある。

平成元年 4 月本会講演大会にて発表 平成 3 年 3 月 25 日受付（Received Mar. 25，1991）

* 豊橋技術科学大学: I博 (Toyohashi University of Technology, 1-1 Hibarigaoka, Tempaku-cho Toyohashi 441)

*2 豊橋技術科学:大学大学院（現：(株)豊田自動織機製作所) (Graduate School, Toyohashi University of Technology, Now TOYOTA Automatic Loom Works, Ltd.)

*3 豊橋技術科学大学大学院 (現: H新製鋼(株)) (Graduate School, Toyohashi University of Technology, Now Nisshin Steel Corp., Ltd.) 


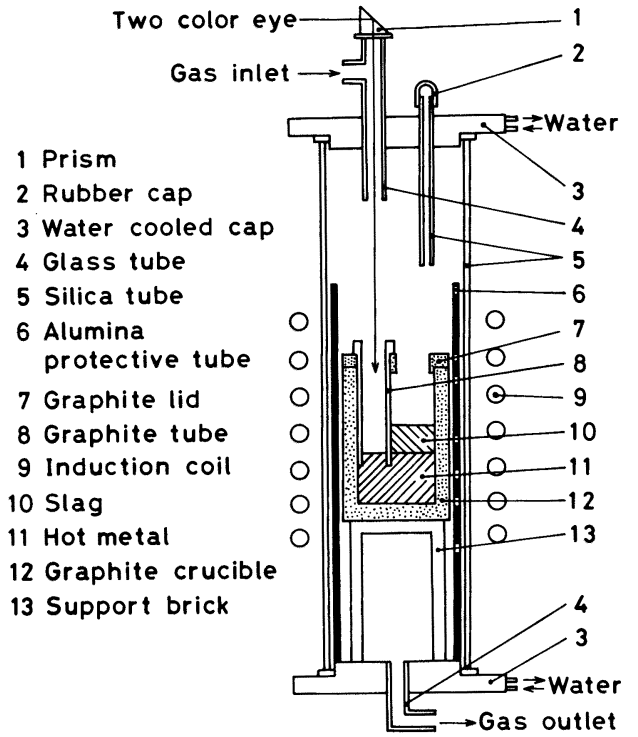

Fig. 1. Schematic diagram of experimental apparatus.

るつぼ, 内径 $38 \mathrm{~mm}$, 深さ $90 \mathrm{~mm}$ の黒鉛製で, 測 温用かつスラグの溶鉄試料採取管への付着防止のための 外径 $14 \mathrm{~mm}$ の黑鉛製浸漬管とそれを支える黒鉛製のふ たを取り付けてある．浸漬管の長さは，その溶鉄中への 浸漬深さを $8,10,13 \mathrm{~mm}$ と変えて予備実験を行った結 果, 浸漬深さの還元速度におよほす影響は認められな かったので，浸漬深さが $10 \mathrm{~mm}$ となるようにした。 ふ たには試料の投入と採取およびガスの流出・入に十分な 大きさの穴を開けてある。

加熱には最大場力 $10 \mathrm{~kW}$ のサイリス夕式高周波発振 機を用い，あらかじめ検定した自動二色温度計でプリズ ムを通して浸漬管内の溶鉄表面温度を測定し， $\pm 10 \mathrm{~K}$ で制御した。

\section{$2 \cdot 2$ クロム鉱石とフラックス}

本実験に使用した南アフリカ産クロム鉱石の化学組成 を Table 1 に示す. 鉱石は粉砕・分級して用いたが, 鉱石サイズによる化学組成に有意差は認められなかっ た。

難溶融性クロム釷石の還元促進とライニングの溶 損防止のために，実際の溶融還元では $\mathrm{CaO}-\mathrm{SiO}_{2}-$ $\mathrm{Al}_{2} \mathrm{O}_{3}-\mathrm{MgO} 4$ 元系フラックスが用いられている ${ }^{15)}$. そ こで, フラックス組成は, Table 2 に示すように $(\mathrm{CaO})$ $/\left(\mathrm{SiO}_{2}\right)$ (以後塩基度と呼ぶ $)=1$ として $\left(\mathrm{Al}_{2} \mathrm{O}_{3}\right)$ と $(\mathrm{MgO})$ の添加量を変えたフラックス Nos. $1 \sim 8$ とフ ラックス Nos. 5, 6 の $\left(\mathrm{Al}_{2} \mathrm{O}_{3}\right)$ と $(\mathrm{MgO})$ の添加量を
Table 1. Chemical composition of chromite ore (mass \%).

\begin{tabular}{cccccccccc}
\hline $\mathrm{Cr}_{2} \mathrm{O}_{3}$ & $\mathrm{FeO}$ & $\mathrm{CaO}$ & $\mathrm{MgO}$ & $\mathrm{Al}_{2} \mathrm{O}_{3}$ & $\mathrm{SiO}_{2}$ & $\mathrm{C}$ & $\mathrm{S}$ & $\mathrm{P}_{2} \mathrm{O}_{5}$ & $\mathrm{Cr} / \mathrm{Fe}$ \\
\hline 44.8 & 25.3 & 0.8 & 10.3 & 14.5 & 3.0 & 0.019 & 0.007 & 0.007 & 1.56 \\
\hline
\end{tabular}

Table 2. Chemical composition of fluxes (mass \%).

\begin{tabular}{c|c|c|c|c|c}
\hline $\begin{array}{c}\text { Flux } \\
\text { No. }\end{array}$ & $\mathrm{CaO}$ & $\mathrm{SiO}_{2}$ & $\mathrm{Al}_{2} \mathrm{O}_{3}$ & $\mathrm{MgO}$ & $\frac{\mathrm{CaO}}{\mathrm{SiO}_{2}}$ \\
\hline 1 & 45.0 & 45.0 & 5 & 5 & 1.00 \\
2 & 42.5 & 42.5 & 5 & 10 & 1.00 \\
3 & 42.5 & 42.5 & 10 & 5 & 1.00 \\
4 & 40.0 & 40.0 & 10 & 10 & 1.00 \\
5 & 42.5 & 42.5 & 15 & 0 & 1.00 \\
6 & 40.0 & 40.0 & 15 & 5 & 1.00 \\
7 & 37.5 & 37.5 & 15 & 10 & 1.00 \\
8 & 35.0 & 35.0 & 15 & 15 & 1.00 \\
9 & 36.4 & 48.6 & 15 & 0 & 0.75 \\
10 & 47.2 & 37.8 & 15 & 0 & 1.25 \\
11 & 26.7 & 53.3 & 15 & 5 & 0.50 \\
12 & 34.3 & 45.7 & 15 & 5 & 0.75 \\
13 & 44.4 & 35.6 & 15 & 5 & 1.25 \\
\hline
\end{tabular}

基にして塩基度を変えたフラックス Nos. 9〜13を選定 し，溶融還元におよほすフラックス組成の影響を系 統的に調べた.フラックスは試薬 1 級の $\mathrm{CaO}, \mathrm{SiO}_{2}$, $\mathrm{Al}_{2} \mathrm{O}_{3}$ と $\mathrm{MgO}$ を所定の割合で配合, 混合し, 黑鉛るつ ぼ中で加熱溶解後, 鉄板上で急冷した，組成の均一化を 网るため，さらにそれを粉砕し，溶解急冷したものを実 験に使用した。

\section{$2 \cdot 3$ 実験手順}

電解鉄（99.9 mass％） $2.3 \times 10^{-1} \mathrm{~kg}$ と黒鉛粉末 $1 \times$ $10^{-2} \mathrm{~kg}$ を黒鉛るつぼ内に入れ, 高周波誘導炉内に設置 した。高純度アルゴン $(99.995 \mathrm{~mol} \%)$ あるいは CO (99.99mol\%）を $1.7 \times 10^{-6} \mathrm{Nm}^{3} / \mathrm{s}$ で流しながら加熱溶 解後, 溶鉄中炭素を飽和にするために所定温度で約 1.2 $\mathrm{ks}$ 保持した. その後, 所定量のクロム鉣石とフラック スを浸漬管とるつほの間の溶鉄表面上にこの順で $60 \mathrm{~s}$ 以内に添加し，実験を開始した．実験条件を Table 3 にまとめて示した.

鉱石の溶融還元挙動を溶鉄に回収されたクロム量とス ラグ組成の経時変化を追跡して調査した。溶鉄試料は,

Table 3. Experimental conditions.

\begin{tabular}{l|c|c}
\hline & $\begin{array}{c}\text { Effect of flux } \\
\text { composition }\end{array}$ & $\begin{array}{c}\text { Effect of dissolution of } \\
\text { chromite ore }\end{array}$ \\
\hline Ore size $(\mu \mathrm{m})$ & $53 \sim 105$ & $53 \sim 105,105 \sim 210.210 \sim 297$ \\
\hline $\begin{array}{l}\text { Ore weight } \\
\text { Flux weight }\end{array}$ & 1.0 & $0.25 \sim 1.00$ \\
\hline $\begin{array}{l}\text { Flux weight } \\
\left(\times 10^{-2} \mathrm{~kg}\right)\end{array}$ & 1.5 & 1.5 \\
\hline Atmosphere & $\mathrm{Ar}, \mathrm{CO}$ & $\mathrm{Ar}$ \\
\hline Temperature $(\mathrm{K})$ & $1663 \sim 1953$ & 1783,1843 \\
\hline
\end{tabular}




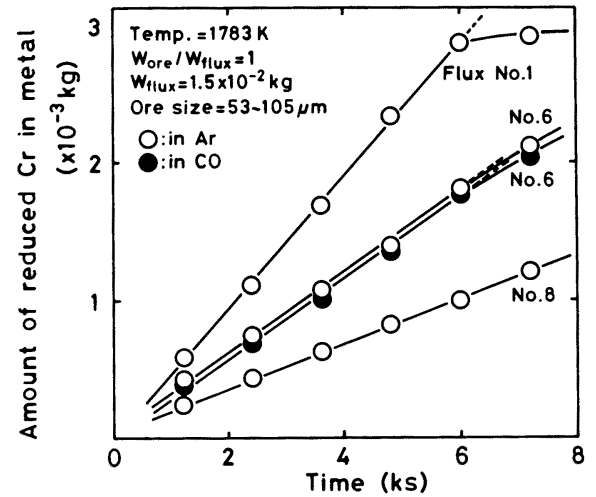

Fig. 2. Change in amount of reduced chromium in metal with time.

内径 $3 \mathrm{~mm}$ の石英管で約 $5 \times 10^{-3} \mathrm{~kg}$ の溶鉄を適当な時 間間隔で吸引後，水中で急冷して採取した，溶鉄中のク 口ムの分析は, 湿式の滴定法 (JIS G 1217) で行った. 鉱石中の酸化鉄が還元され溶鉄に全量回収されても，そ の量は大きいものでも $4.4 \times 10^{-3} \mathrm{~kg}$ であるので, これ による溶鉄重量変化は無視できる，そこで，試料採取に よる溶鉄重量変化のみを考慮して分析値より溶鉄に回収 されたクロム質量を算出した。

スラグ試料は，先端を細く加工した石英管をスラグに 浸漬し, 約 $2 \times 10^{-4} \mathrm{~kg}$ のスラグを付着させ水中で急冷 して採取した。採取した試料を SEM で観察し，EPMA で組成を調べた。

\section{3. 実 験 結 果}

\section{$3 \cdot 1$ 溶鉄中のクロム再の経時変化と雾囲気の影䇺}

溶鉄中に回収されたクロム量の経時変化を Fig. 2 に 例示する.フラックスは添加後約 $0.12 \mathrm{ks}$ 以内で溶解し, その直後よりスラグは泡立ち始める. 溶鉄に回収された クロム量は実験条件によらず直線的に増大した後, 増加 割合は小さくなる.従来クロム鉱石の溶融還元速度は, ス ラグ中の全クロム量が 3 mass $\%^{16)}$ あるいは 8 mass\% ${ }^{17)}$ 以上あれば還元反応は見かけ上 0 次反応速度式で表さ れることが報告されている. そこでクロム量が直線的に 增大寸るその傾きを 0 次皮応の還元速度 $d \mathrm{Cr} / d t$ とみ なし, 以後評価に用いる. $\left(\mathrm{Al}_{2} \mathrm{O}_{3}\right)+(\mathrm{MgO})$ が一番小 さいフラックス No. 1 を用いた場合の還元速度は一番大 きく, $\left(\mathrm{Al}_{2} \mathrm{O}_{3}\right)+(\mathrm{MgO})$ の増大とともにそれは小さく なる。网には $\mathrm{CO}$ 気流中でのクロム量の経時変化もあ わせて示した，溶融シリカの鉄中炭素による還元におい て, $\mathrm{Ar}$ 気流中の還元速度は $\mathrm{CO}$ 気流中のそれよりも約 2 倍大きいことが報告されているが18), 本実験で得られ

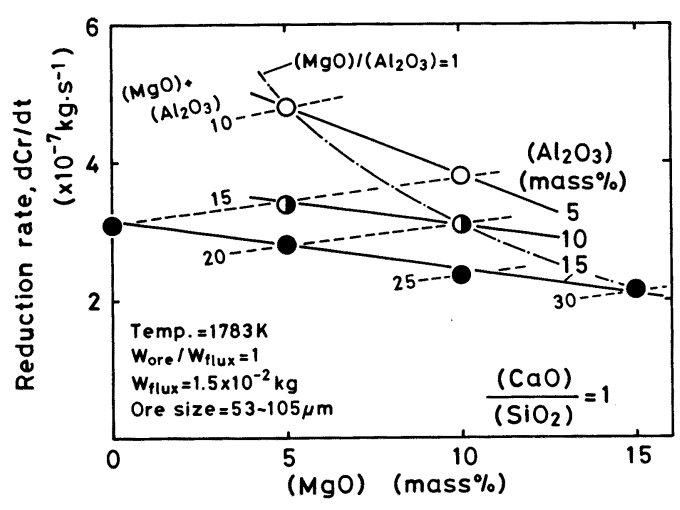

Fig. 3. Effects of $(\mathrm{MgO})$ and $\left(\mathrm{Al}_{2} \mathrm{O}_{3}\right)$ on reduction rate.

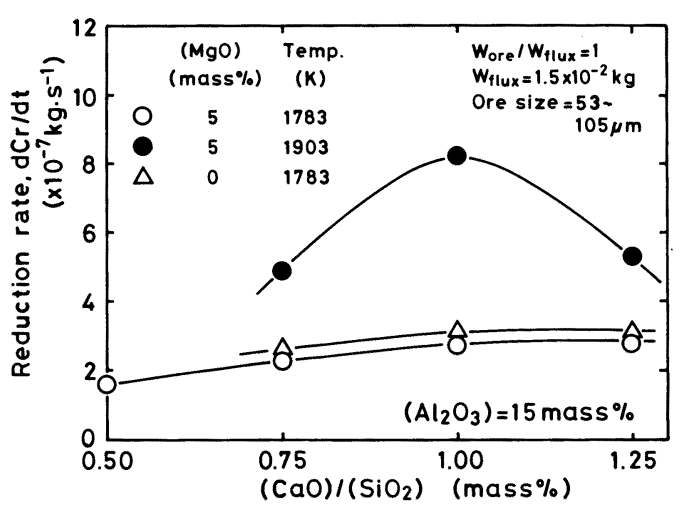

Fig. 4. Effect of $(\mathrm{CaO}) /\left(\mathrm{SiO}_{2}\right)$ on reduction rate.

た還元速度は䨌囲気によらずほぼ同じであることが図よ りわかる.

\section{$3 \cdot 2$ 還元速度におよぼすフラックス組成の影㹃}

還元速度におよぼすフラックス中の $(\mathrm{MgO})$ と $\left(\mathrm{Al}_{2} \mathrm{O}_{3}\right)$ の影響を Fig. 3 に示す. $\left(\mathrm{Al}_{2} \mathrm{O}_{3}\right)$ を一定に保つと, 還 元速度は $(\mathrm{MgO})$ の增大とともに隇少する. $(\mathrm{MgO})$ を 一定とした場合, 還元速度は $\left(\mathrm{Al}_{2} \mathrm{O}_{3}\right)$ の增大とともに 減少するが, その減少割合は $(\mathrm{MgO})$ と比べ大きい. したがって, $(\mathrm{MgO}) /\left(\mathrm{Al}_{2} \mathrm{O}_{3}\right)=1$ に保つと (一点鎖線) $(\mathrm{MgO})+\left(\mathrm{Al}_{2} \mathrm{O}_{3}\right)$ の増加にともなう還元速度の隇少割 合はさらに大きくなる。一方, $\left(\mathrm{Al}_{2} \mathrm{O}_{3}\right)+(\mathrm{MgO})$ を一 定とし $(\mathrm{MgO})$ を増加させると (点線), 還元速度は大 きくなる.

$\left(\mathrm{Al}_{2} \mathrm{O}_{3}\right)=15$ mass\%,$(\mathrm{MgO})=5$ mass\% と一定に保っ た場合の還元速度におよほすす塩基度の影響を Fig. 4 に 示す. 塩基度 $\leqq 1$ では還元速度は温度によらず塩基度と 


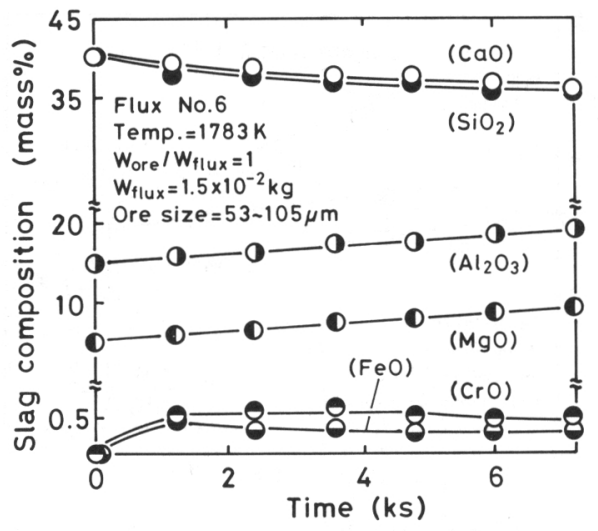

Fig. 5. Change in slag composition with time.

ともに増大する．塩基度 $\geqq 1$ では $1783 \mathrm{~K}$ での還元速度 はほぼ一定となるが，1903 K では減少する，比較のた めに $(\mathrm{MgO})=0$ mass\% の還元速度も示したが，還元速 度は塩基度によらず約 $4 \times 10^{-8} \mathrm{~kg} / \mathrm{s}$ だけ大きくなる。

\section{$3 \cdot 3$ スラグ組成の経時変化}

スラグ組成の経時変化の一例を Fig. 5 に示す.ここ で，スラグ中には鉱石が分散しているので，鉱石を含ま ないスラグ相のみの值を眓示してある. 多くの実験で $(\mathrm{CaO})$ と $\left(\mathrm{SiO}_{2}\right)$ は減少し, $\left(\mathrm{Al}_{2} \mathrm{O}_{3}\right)$ と $(\mathrm{MgO})$ は増 加する.これはそれらの鉱石含有量に差があるため, 後 者の溶解量だけ前者は希釈されたと考えられる。一方, $\left(\mathrm{Al}_{2} \mathrm{O}_{3}\right)+(\mathrm{MgO})$ が最大のフラックス No. 8 を用いた $1783 \mathrm{~K}$ での実験では, 約 $0.12 \mathrm{ks}$ で $\left(\mathrm{Al}_{2} \mathrm{O}_{3}\right)$ と $(\mathrm{MgO})$ は最小かつ $(\mathrm{CaO})$ と $\left(\mathrm{SiO}_{2}\right)$ は最大の值を示した後, 初期組成と比べて前者は若干小さい值, 後者は大きい値 で一定となった。溶存クロム酸化物は, 実験終了後のス ラグが濃青色であったので，2 価の $\mathrm{CrO}$ とした ${ }^{19) 20)}$

$(\mathrm{CrO})$ は，ほぼ一定の值を示した後減少した。この一定 の值を示す期間は 0 次反応とみなせるそれとほほ同等 であった（ $\mathrm{FeO})$ はフラックス溶解直後では大きくそ の後減少した。

\section{$3 \cdot 4$ スラグ中のクロム鉱石}

スラグ中のクロム鉱石の一例を Photo. 1 (a)に, ま たその部分拡大図を Photo. 1(b) に示す。鉱石内とその 表面には層状と球状のクロムをほとんど含まない金属鉄 が認められた。スラグ中の鉱石形状は元の粉末形状を反 映して角ばっており，鉱石は内部の原鉱石部と外側の表 面層の 2 相より形成されていた。この表面層は時間と ともに厚くなる傾向がみられた.

Photo. 1(c) に Photo. 1(b) 中の線に沿った EPMA による鉱石ースラグ界面近傍の線分析の結果を示す。 $\mathrm{Al}$
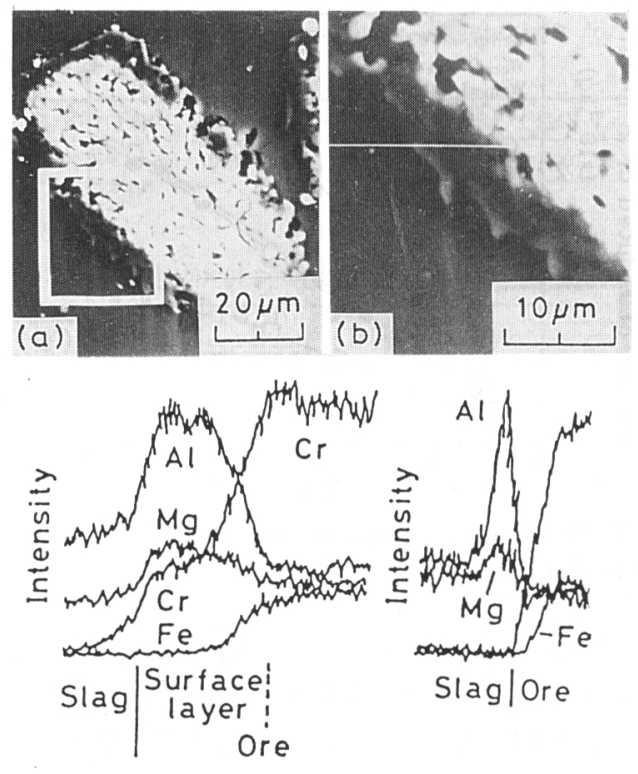

(c)

(d)

(a) (b) (c) Reduced at $1783 \mathrm{~K}$ for $2.4 \mathrm{ks}$ in flux No. 6 (d) Reduced at $1783 \mathrm{~K}$ for $3.6 \mathrm{ks}$ in flux No. 8

Photo. 1. Chromite ore in flux and intensity curves.

と $\mathrm{Mg}$ の濃度は表面層内で一定であるが, スラグ相お よび原鉱石部と比べるとその值は大きい，Cr は原鉱石 部から表面層の中心部にかけて濃度勾配があり, 表面層 内のスラグ界面近傍で一定の值を示すＦe の濃度勾配 は原鉱石部と表面層との境界にかけて存在し， Cr の濃 度勾配の存在する位置よりも内部にある。したがって鉱 石中の $\mathrm{Fe}$ は $\mathrm{Cr}$ よりも溶解しやすいと考えられる。 ま た表面層内には $\mathrm{Fe}$ はほとんど認められない。 $\mathrm{Ca}$ と $\mathrm{Si}$ の濃度は同図には示していないが，スラグ相中で一定の 值を示し，スラグ相と表面層との界面のスラグ側でその 濃度は急激に小さくなる. $\mathrm{Al}$ と $\mathrm{Mg}$ の濃度の大きい表 面層の生成機構としては, 前述したようにスラグ中の $\left(\mathrm{Al}_{2} \mathrm{O}_{3}\right)$ と $(\mathrm{MgO})$ は単調に増加しているので，スラ グ中のそれらの成分が鉱石表面に晶出する機構は考えに くい.したがって鉱石中の $\mathrm{Al}$ と $\mathrm{Mg}$ の溶解速度が $\mathrm{Cr}$ と $\mathrm{Fe}$ のそれよりも小さいために, 結果として表面部分 の $\mathrm{Al}$ と $\mathrm{Mg}$ 濃度の值が大きくなったものと思われる.

Photo. 1(d) には $\left(\mathrm{Al}_{2} \mathrm{O}_{3}\right)+(\mathrm{MgO})$ が 30 mass\% と 最大のフラックス No. 8 を用い, $1783 \mathrm{~K}$ で実験した場 合の鉱石ースラグ界面近傍の線分析の結果を示す。スラ グおよび鉱石とは異なる灰色がかった相がスラグ中の鉱 石ースラグ界面にあったが，これは $\mathrm{Al}$ と $\mathrm{Mg}$ の大きい 
相で $\mathrm{Cr}$ と $\mathrm{Fe}$ はほとんどない。この相は， $1843 \mathrm{~K}$ で の実験においては認められなかった. 前述した $\left(\mathrm{Al}_{2} \mathrm{O}_{3}\right)$ と $(\mathrm{MgO})$ の挙動から推測すると,このフラックス組 成は実験温度ではスピネルが晶出する液相線組成に近い ことから, 鉱石とフラックス添加後の溶解時において, $\left(\mathrm{Al}_{2} \mathrm{O}_{3}\right)$ と $(\mathrm{MgO})$ が同じスピネル構造をもつクロム 鉱石を核として晶出し, 実験温度に到達後もそれらは一 部溶解せずに鉱石表面に残ったと考えられる。

\section{4. 考察}

\section{$4 \cdot 1$ スラグ中への鉱石への溶解過程}

前述したように, 多くの実験でスラグ中のクロム鉱石スラグ界面に $\mathrm{Al}$ と $\mathrm{Mg}$ 濃度の大きい相の存在が認めら れたので, クロム鉣石の溶融還元反応は鈗石のスラグへ の溶解過程に律速されることが予想される.もし鉱石の 溶解が律速過程であるならば, 還元速度と（CrO）濃度 は鉱石ースラグ界面積に依存するはずである。

鉱石サイズおよび鉙石とフラックスの重量比を変えた 実験について、還元速度と鉱石一スラグ界面積との関係 を Fig. 6 に示す. 界面積の值は, 鉱石形状を球と仮定し,

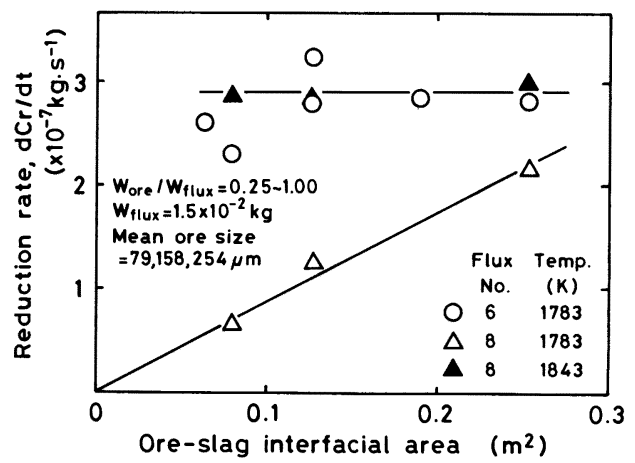

Fig. 6. Effect of ore-slag interfacial area on reduction rate.

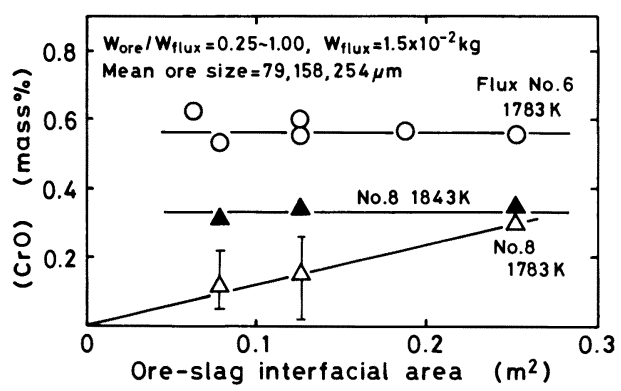

Fig. 7. Effect of ore-slag interfacial area on ( $\mathrm{CrO})$.
平均鉱石より算出した. $1783 \mathrm{~K}$ では, フラックス No. 6 を用いた場合の還元速度と界面積との間には相関は認 められないが, フラックス No. 8 を用いた場合の還元速 度は界面積に比例して大きくなるのがわかる．同じフ ラックス No. 8 を用いても，温度が $1843 \mathrm{~K}$ の場合には 還元速度の界面積依存性はなくなる。

( $\mathrm{CrO})$ と鉱石ースラグ界面積との関係を Fig. 7 に示 す.ここで（ $\mathrm{CrO})$ は 0 次反期間でほぼ一定な值を平 均して図示した。 ただしフラックス No. 8 を用いて平均 鉱石サイズ $158 \mu \mathrm{m}$ 以上の鉱石を $1783 \mathrm{~K}$ で還元した場 合, スラグは青色と白色の部分が混在し $(\mathrm{CrO})$ の值は ばらついたので, 最大值と最小値を濃度範囲として平均 值とともに示してある. $1783 \mathrm{~K}$ では, フラックス No. 6 を用いた場合の（CrO）は界面積によらずほぼ一定な 值を示すが, フラックス No. 8 を用いた場合の $(\mathrm{CrO})$ は界面積に比例して大きくなる．同じフラックス No. 8 を用いても温度が $1843 \mathrm{~K}$ の場合には還元速度の界面積 依存性はなくなる.

以上のことよりフラックス No. 6 と $1843 \mathrm{~K}$ でフラッ クス No. 8 を用いた場合の溶融還元反応は鉱石のスラグ への溶解過程に律速されないが, $1783 \mathrm{~K}$ でフラックス No. 8 を用いた場合のそれは溶解過程に律速されている ことがわかる. したがって Photo.1(c) に示した鉱石内 の $\mathrm{Al}$ と $\mathrm{Mg}$ の濃度の大きい表面層は還元反応を溶解律 速とするものではなく, Photo. 1(d) に示したスラグ相 内にある $\mathrm{Al}$ と $\mathrm{Mg}$ の高い相は溶解を阻害し, 還元反応 を溶解律速とする原因であることがわかる.このことは, 前述したスラグ組成の経時変化からも襄付けられる。 た, $1783 \mathrm{~K}$ でフラックス No. 8 を用いた場合を除いて, 0 次反応期間の $(\mathrm{CrO})$ は鉱石一スラグ界面積の影響を 受けないので, 飽和溶解度であると判断される.

なお，Fig. 6 に示したフラックス No. 6 を用いた場合 の還元速度のばらつきは，実験終了後に測定した黒鉛一 スラグ界面積のそれとよく対応していた．本実験は黒鉛 るつぼを用いているため, 反応サイトとして溶鉄-スラ グ界面と黒鉛-スラグ界面の二つが挙げられる.したがっ て，還元速度が黒鉛-スラグ界面積により異なったと考 えられるが，これについては続報で述べる．

\section{$4 \cdot 2$ 還元速度におよぼす温度とスラグ粘性の影䈏}

従来, スラグ中クロム酸化物の還元反応は, 濃度の 1 次式で表されている ${ }^{19) 21)}$ ，そこで，本実験での溶融還 元反応速度も濃度の一次式で表されると仮定すると

$$
d \mathrm{Cr} / d t=k(\% \mathrm{CrO}) \text {. }
$$

となる.ここで $k$ は速度定数である．溶鉄に回収され たクロム量が直線的に増大する間 $(\mathrm{CrO})$ は時間変化し 


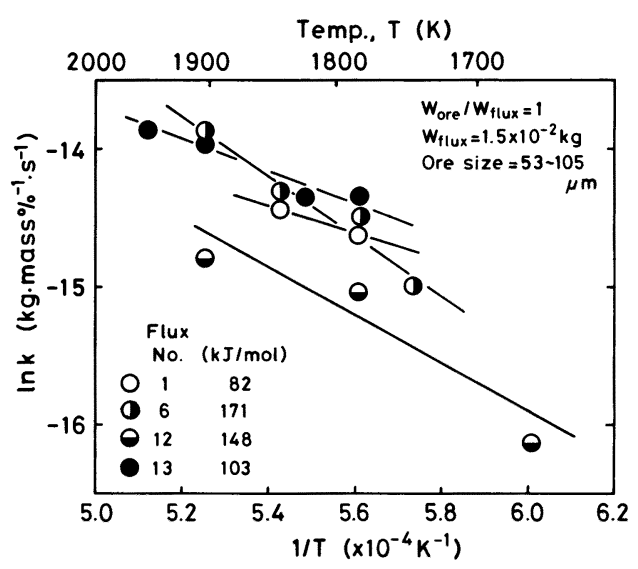

Fig. 8. Arrhenius plots of rate constants.

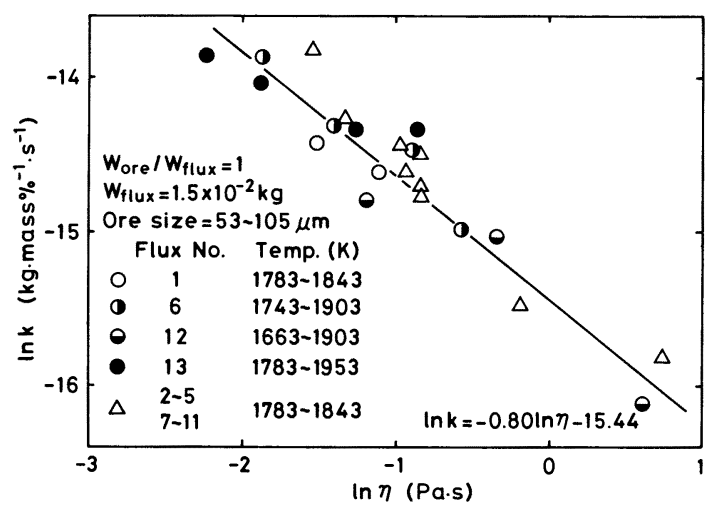

Fig. 9. Relation between rate constant and slag viscositv $\eta$.

ないので，それは定数として扱え反応はみかけ上 0 次 反応となる。そこで式( 1 )より速度定数を算出し, 得ら れた值をアレニウスプロットとして Fig. 8 に示す.す ベてのフラックスでほぼ直線関係が得られ，見かけの活 性化エネルギーは 100 $171 \mathrm{~kJ} / \mathrm{mol}$ の值となる。これら の值は, MAEDA ら ${ }^{21)}$ がスラグ側物質移動律速として得 た $109 \mathrm{~kJ} / \mathrm{mol}$ に近く, 藤田ら ${ }^{14)}$ の $305 \mathrm{~kJ} / \mathrm{mol}$ とはかけ はなれていた。なお，ばらつきの原因としては，前述し たように黒鉛ースラグ界面での反応の寄与に差があるた めであると考えられる.

もし還元反応がスラグ側の物質移動律速であるなら ば，速度定数はスラグ粘性と関連があると考えられる。

Fig. 9 に速度定数とスラグ粘性 $\eta$ の関係を示す.ここ でスラグ粘性は, MACHIN ら ${ }^{22)}$ の值をもとにして推算 した。また，溶解の影響を受けるフラックス No. 8の
$1783 \mathrm{~K}$ での值は除外してある。温度およびフラックス 組成によらず速度定数はスラグ粘性と $k=1.97 \times 10^{-7}$ $\eta^{-0.8}$ の式で関係づけられる. 藤田ら ${ }^{14)}$ は 1 次反応の 速度定数 $k_{1}$ とスラグ粘性との間に $k_{1}=6.64 \times 10^{-4}$ $\eta^{-0.429}$ の関係を得ている. 本実験の還元速度の粘性依 存性は藤田らのそれよりも約 2 倍大きいが, 速度定数 は温度およびフラックス組成によらずスラグ粘性により 一義的に表されるので，還元反応はスラグ側の物質移動 律速であると推定される。

\section{$4 \cdot 3$ スラグ中の $\mathrm{CrO}$ 漕度}

$4 \cdot 1$ 節で述べたように 0 次反応期間におけるスラグ中 ( $\mathrm{CrO})$ 濃度は, $1783 \mathrm{~K}$ でフラックス No. 8 を用いた実 験を除いてスラグへの飽和溶解度であると考えられる. そこで, 飽和溶解度におよほすフラックス組成と温度の 影響について調べてみた。

$\left(\mathrm{Al}_{2} \mathrm{O}_{3}\right)$ と $(\mathrm{MgO})$ 濃度の影響を Fig. 10 に示す.フ ラックス中の（ $\mathrm{MgO} ）$ が増加すると（CrO）濃度は低 下するが $\left(\mathrm{Al}_{2} \mathrm{O}_{3}\right)=15$ mass \%で $(\mathrm{MgO}) \geqq 5$ mass\% で はその值はほほ一定となる。一方 $(\mathrm{MgO})=5$ mass\% で は $\left(\mathrm{Al}_{2} \mathrm{O}_{3}\right)$ が増大すると $(\mathrm{CrO})$ は低下するが, $(\mathrm{MgO})$ $=10 \mathrm{mass} \%$ では $\left(\mathrm{Al}_{2} \mathrm{O}_{3}\right)$ 濃度によらずほぼ一定な值 となった。同図には $\mathrm{CO}$ 気流中での実験結果もあわせ

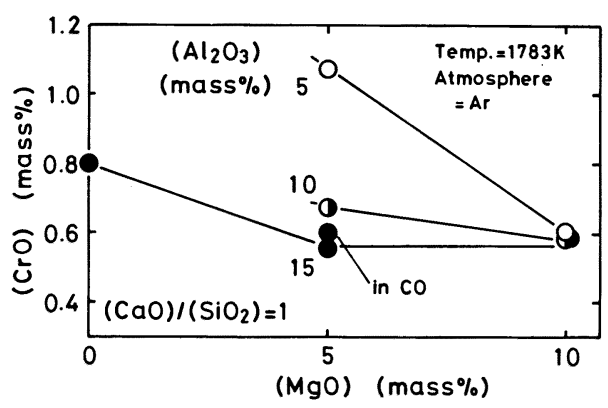

Fig. 10. Effects of $(\mathrm{MgO})$ and $\left(\mathrm{Al}_{2} \mathrm{O}_{3}\right)$ on $(\mathrm{CrO})$.

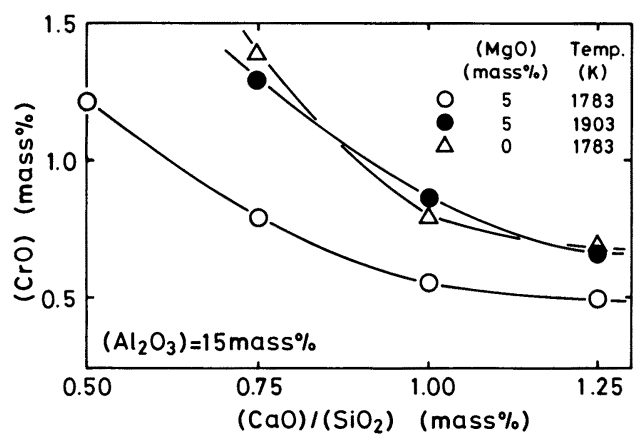

Fig. 11. Effect of $(\mathrm{CaO}) /\left(\mathrm{SiO}_{2}\right)$ on $(\mathrm{CrO})$. 


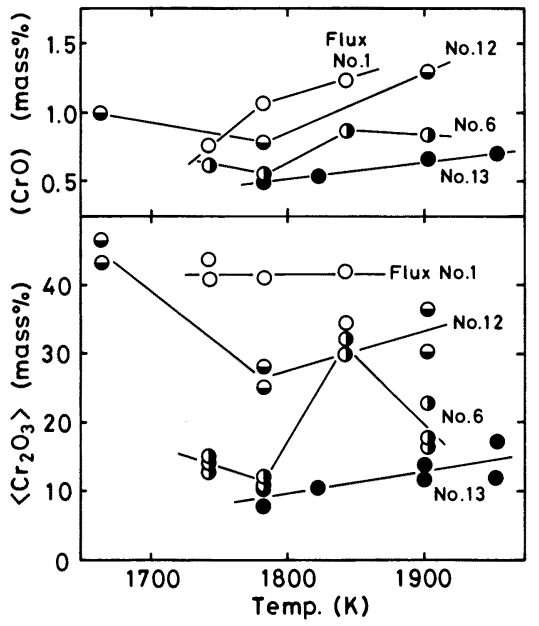

Fig. 12. Effect of temperature on $(\mathrm{CrO})$ and $\left.<\mathrm{Cr}_{2} \mathrm{O}_{3}\right\rangle$.

て示したが，雲囲気の相違による有意差とは認められな い.

フラックス中の塩基度の影響を Fig. 11 に示す。 $(\mathrm{CrO})$ の值は塩基度が大きくなるにつれて小さくなる のがわかる．また温度が高くなると（ $\mathrm{CrO} ）$ の值も大き くなる．前述した $(\mathrm{MgO})$ の影響が同図においても認 められ, $(\mathrm{MgO})$ が増加すると $(\mathrm{CrO})$ の值は小さくなっ ている．これらのことから， $\mathrm{CrO}$ は塩基性成分である と考えられる.

なお, 本実験で得られた飽和溶解度とフラックス組成 の関係はピクロクロマイトのそれ ${ }^{23)}$ と定性的には一致 している.

温度の影響を Fig. 12 に示す. 温度が大きくなるとフ ラックス No. 1 とフラックス No. 13 の ( CrO) は増大 するが, フラックス No. 6 と No. 12 は複雑な挙動を示 す.

$3 \cdot 5$ 節で述べたように鉱石中のスラグー鉱石界面には, $\mathrm{Al}$ と $\mathrm{Mg}$ 濃度の大きい表面層があるので, 飽和溶解度 は鉱石内の表面層組成についてのものであると思われ る. そこで, Photo. 1(c) に示した表面層内のクロム濃 度がプラトーな位置の組成を EPMA で点分析して Fig. 12 にあわせてある. ここで, 表面層組成は $\left\langle\mathrm{Cr}_{2} \mathrm{O}_{3}>\right.$ （く>は固相を表す)が約 20 mass\% 以上ではピク口 クロマイトースピネル固溶線上にあるが, それ以下では その固溶線上より $\mathrm{Al}_{2} \mathrm{O}_{3}$ rich 側の組成になる. 表面層 のクロム濃度はフラックス No. 1 では温度によらずほほ 一定な值であるが, フラックス No. 13 は温度とともに 増大し, フラックス No. 6 と No.12 では温度に対して

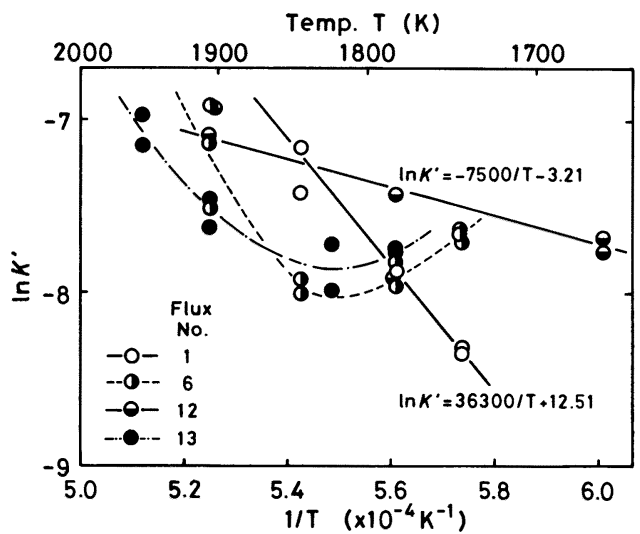

Fig. 13. Relation between apparent equilibrium constant and temperature.

複雑な挙動を示すが，その大小関係は（CrO）のそれと 対応している.

そこで, 溶解反応を

$<\mathrm{Cr}_{2} \mathrm{O}_{3}>=2(\mathrm{CrO})+(\mathrm{O})$

(O) $+\mathrm{C}=\mathrm{CO}$

の素反応過程の組合せと考えると,

$<\mathrm{Cr}_{2} \mathrm{O}_{3}>+\mathrm{C}=2(\mathrm{CrO})+\mathrm{CO}$

となる．本実験では， $a_{\mathrm{C}}=1, P_{\mathrm{CO}}=101.53 \mathrm{kPa}$ が仮定 できるので, みかけの平衡定数 $K^{\prime}$ は真の平衡定数を $K$ として

$$
K^{\prime}\left(=\frac{N^{2}{ }_{\mathrm{CrO}}}{N_{\mathrm{Cr}_{2} \mathrm{O}_{3}}}\right)=K \frac{\gamma_{\mathrm{Cr}_{2} \mathrm{O}_{3}}}{\gamma^{2}{ }_{\mathrm{CrO}}}
$$

と変形できる. そこで $\ln K^{\prime}$ を $1 / T$ で整理して Fig. 13 に示す. フラックス No. 1 とフラックス No. 12 につい ては良好な直線関係が得られ，Fig. 12 に示したフラッ クス No. 12 の ( $\mathrm{CrO})$ の挙動は表面層の $<\mathrm{Cr}_{2} \mathrm{O}_{3}>$ 濃 度の変化で説明できる. フラックス No. 6 とフラックス No. 13 については下に凸な曲線関係となった．本解析 では，活量ではなく濃度を用いていること，クロムの酸 化状態を（CrO）と< $\mathrm{Cr}_{2} \mathrm{O}_{3}>$ としていることにも問題 がある ${ }^{23) 24)}$. またフラックス No. 6 と No. 13 で曲線関 係となる原因として, 表面層組成がピクロクロマイトスピネル固溶線上より $\mathrm{Al}_{2} \mathrm{O}_{3}$ rich 側にはずれているこ とが挙げられるので, 表面層組成と飽和溶解度の関係は さらに検討しなければならない.

\section{5. 結言}

スラグ中クロム鉣石を炭素飽和鉄を含む黒鉛るつぼ中 で還元する実験を行った．還元前期においては還元は見 かけ上 0 次反応で進行する. そこでこの 0 次反応速度 
におよぼすフラックス組成の影響について検討した。

得られた結果を要約して以下に記す。

( 1 ) 還元速度は $\left(\mathrm{Al}_{2} \mathrm{O}_{3}\right)$ と $(\mathrm{MgO})$ 濃度が, 特に前 者が増大すると減少した。 また $(\mathrm{CaO}) /\left(\mathrm{SiO}_{2}\right)$ の増大 に伴い還元速度は大きくなるが, $(\mathrm{CaO}) /\left(\mathrm{SiO}_{2}\right) \geqq 1$ で は $1783 \mathrm{~K}$ の還元速度は $(\mathrm{CaO}) /\left(\mathrm{SiO}_{2}\right)$ によらずほぼ 一定になったが, $1903 \mathrm{~K}$ のそれは $(\mathrm{CaO}) /\left(\mathrm{SiO}_{2}\right)$ の 増大とともに減少した。

( 2 ) $1783 \mathrm{~K}$ で $(\mathrm{CaO}) /\left(\mathrm{SiO}_{2}\right)=1,\left(\mathrm{Al}_{2} \mathrm{O}_{3}\right)=(\mathrm{MgO})$ $=15$ mass\% のフラックスを用いると還元速度は鉱石の スラグへの溶解に律速されるが，それ以外のフラックス と温度では鉱石表面に $\mathrm{Al}$ と $\mathrm{Mg}$ 濃度の大きい表面層が 存在しても還元反応は溶解に律速されない.

( 3 )還元反応が鉣石の溶解に影響されないとき，0次 反応期間のスラグ中の溶存クロム酸化物濃度は飽和溶解 度であり，その值と鉱石中の表面層組成とからみかけの 平衡定数を見積もった.

(4)速度定数 $k$ は温度およびフラックス組成によら ずスラグ粘性と $k=1.97 \times 10^{-7} \eta^{-0.80}$ で関係づけら れ，反応はスラグ側の物質移動律速と推定された.

本研究を遂行するにあたり実験に協力していただいた 高柳吉樹氏（現：豊和工業株式会社）ならびに EPMA 分析に協力していただいた文部技官白井宏始氏に感謝の 意を表します。

\section{文献}

1 ) M. KawaKami and $K$. Ito: Proc. 4th Japan-Nordic Countries Joint Symp., Tokyo (1986), p. 136

2 ) 高岡利夫, 菊地良輝, 河井良彦: 鉄と鋼, 76 (1990), p. 1839

3 ) 竹内透次, 仲村秀夫, 桜谷敏和, 藤井徹也, 野崎 努: 鉄と鋼, 76 (1990), p. 1847

4 ) 田岡啓造, 多田 睦, 山田純夫, 野材 寛, 大西正之,
馬田一: 鉄と鋼, 76 (1990), p. 1863

5 ) 川上正博, 伊藤公允, 吉賀博文, 野間正泰, 奥山 優: 電気製鋼，58 (1987), p. 4

6 ) 川上正博, 北島要春, 橋本 薰, 伊藤公允: 鉄と鋼, 73 (1987), p. 820

7 ) $M$. Kawakami, $Y$. Kitajima, $K$, Нashimoto and $K$. Ito: Trans. Iron Steel Inst. Jpn., 27 (1987), p. 176

8 ) $M$. Kawakami, $H$. Yoshiga, $Y$. Kitajima, $M$. Noma and $K$. Iто: The Fifth International Congress, Washington, ISS-AIME (1986), p. 751

9 ) $M$. Kawakami, $Y$. Kitajima, $K$. Hashimoto and $K$. Ito: Proc. Shenyang Intern. Symp. Smelting Reduction, Shenyang (1986), p. 115

10）角戸三男, 稲谷稔宏, 高田至康, 片山英司, 浜田尚夫, 槌谷暢男: 鉄と鋼, 69 (1983), S12

11）山名 寿, 佐藤哲朗, 片桐 望, 尾上俊雄: 鉄と鋼, 71 (1985), S143

12）丸川雄浄, 姉崎正治, 平田武行, 加藤木健, 石川 稔: 鉄 と鋼, $72(1986), \mathrm{S} 112$

13）深川 信, 下田輝久: 鉄と鋼, 74 (1988), p. 286

14）藤田正樹, 片山裕之, 桑原正年, 斉藤 力, 石川英毅, 梶阙博幸: 鉄と鋼, 74 (1988), p. 680

15）片山裕之, 桑原正年, 平田 浩, 八木次朗, 斉藤 力, 藤田正樹: 鉄と鋼, 76 (1990), p. 1855

16）桑原正年, 片山裕之, 石川英毅, 藤田正樹, 佐々木俊明: 鉄と鋼, 70 (1984), S116

17）丸川雄净, 姉崎正治, 平田武行, 石川 稳: 学振 19 委一 No. 10708 (昭和 61 年 2 月）

18）川合保治, 森 克己, 坂口光司: 鉄と鋼, 56 (1970), p. 1447

19) C. W. McCoy and W. O. Philbrook: Trans. Metall. Soc. AIME, 212 (1958), p. 226

20）森田一樹, 佐野信雄: 鉄と鋼, 74 (1988), p. 2361

21) M. Maeda, $N$. Sano and Y. Matsushita: Conservation and Recycling, 4 (1981), p. 137

22) J. S. Machin and D. L. Hanna: J. Am. Ceram. Soc., 28 (1945), p. 310 J. S. MACHin and T. B. YEE: J. Am. Ceram. Soc., 31 (1948), p. 200

23）森田一樹, 井上明彦, 高山直樹, 佐野信雄: 鉄と鋼, 74 (1988), p. 999

24) C. Greskovich and V. S. Stubcan: J. Phys. Chem. Solid, 27 (1966), p. 1379 